\title{
Physical and genetic map of the genome of Campylobacter upsaliensis
}

\author{
Billy Bourke, ${ }^{1,2,3}$ Philip Sherman, ${ }^{1,2,3}$ Helena Louie, ${ }^{3}$ Eric Hani, ${ }^{3}$ \\ Praveen Islur ${ }^{1}$ and Voon L. Chan ${ }^{3}$
}

1 Division of

Gastroenterology,

Research Institute, The Hospital for Sick Children, Toronto, Ontario, Canada M5G 1X8

2,3 Departments of Pediatrics ${ }^{2}$ and Microbiology ${ }^{3}$, University of Toronto, Toronto, Ontario, Canada M5S 1A8

\author{
Author for correspondence: Voon L. Chan. Tel: +1 416978 6077. Fax: +1 4169784761. \\ e-mail: vichan@gpu.utcc.utoronto.ca
}

\begin{abstract}
A physical map of Campylobacter upsaliensis ATCC 43954 was constructed from DNA fragments generated by Sall (5' G/TCGAC), Narl (5' GG/CGCC) and BssHII (5' G/CGCGC) restriction digests separated using pulsed-field gel electrophoresis. The size of the $C$. upsaliensis genome was approximately $2000 \mathrm{~kb}$, providing evidence of the largest Campylobacter genome sized to date. Twenty-one fragments created from these restriction digests were assembled into a physical map using a combination of complementary methods including cross-Southern hybridization, hybridization fingerprint analysis and hybridization with homologous and heterologous (from Campylobacter jejuni) gene probes. The position of ten genetic loci, including that of the iron-uptake regulatory (fur) gene, were localized to the physical map. A genomic library of C. upsaliensis ATCC 43954 was constructed in lambda Gem-11 vector. Fifty thousand recombinants with an average size of $16 \mathrm{~kb}$ represent a library about 200 times the size of the genome. Using $C$. jejuni DNA probes, clones representing C. upsaliensis flaA, fur and ftsZ genes were isolated and localized to the physical map.
\end{abstract}

Keywords: Campylobacter, genomic map

\section{INTRODUCTION}

Campylobacter upsaliensis is increasingly recognized as an important human enteropathogen (Sandstedt et al., 1983; Lastovica et al., 1989; Taylor et al., 1989; Walmsley \& Karmali, 1989). C. upsaliensis is associated with acute selflimiting diarrhoea but it has also been isolated in the setting of chronic diarrhoea and failure to thrive in infants (Megraud \& Bonnet, 1986). Moreover, C. upsaliensis can cause bacteraemia in debilitated and immunocompromised patients (Patton et al., 1989; Chusid et al., 1990). In a recent report (Steele et al., 1985), this thermophilic, catalase-negative Campylobacter species comprised more than one-quarter of all faecal Campylobacter isolates in children under 3 years old. Some reports indicate that $C$. upsaliensis is a more frequent human faecal isolate than Campylobacter coli (Steele et al., 1985; Goossens et al., 1990). Thus, C. upsaliensis may be the second most commonly identified human intestinal campylobacter after Campylobacter jejuni.

Despite its importance in human disease, little is known about the virulence properties of $C$. upsaliensis (Sandstedt
\& Ursing, 1991). Furthermore, the organism remains to be characterized using a molecular biological approach. Genetic characterization of $C$. upsaliensis is an essential step towards understanding at a molecular level the role of this bacterium in human disease.

Pulsed-field gel electrophoresis (PFGE) technology has proven invaluable for the accurate estimation of genome size (Lee \& Smith, 1988; Pyle et al., 1988) and in the construction of physical maps for a diverse range of prokaryotic organisms (Smith et al., 1987; Romling et al., 1989; Allerdet-Servent et al., 1990; Ladefoged \& Christiansen, 1992; Alleman et al., 1993; Murray et al., 1993; Neumann et al., 1993). Physical maps exist for several Campylobacter species including C. jejuni (Chang \& Taylor, 1990; Nuijten et al., 1990; Kim et al., 1992), C. coli (Yan \& Taylor, 1991) and C. fetus (Salama \& Taylor, 1993). Despite its importance as a human enteric pathogen, a genomic map has yet to be developed for $C$. upsaliensis. The generation of a physical and genetic map of C. upsaliensis reported in this manuscript will help direct future gene-cloning and fine-mapping strategies for this organism. 


\section{METHODS}

DNA preparation. The type strain of C. upsaliensis (ATCC 43954/NCTC 11541; American Type Culture Collection, Rockville, MD, USA) was grown at $37^{\circ} \mathrm{C}$ in $7 \%$ (v/v) $\mathrm{CO}_{2}$ in Brucella broth supplemented with $10 \%(\mathrm{v} / \mathrm{v})$ foetal calf serum. To obtain adequate overnight growth, small broth culture volumes were necessary; typically $20-30 \mathrm{ml}$ cultures per $500 \mathrm{ml}$ Erlenmeyer flask. Genomic DNA was prepared in agarose plugs by previously described methods (Smith et al., 1988; Maslow et al., 1993). Briefly, bacterial cultures were centrifuged, washed and resuspended in $10 \mathrm{mM}$ Tris $/ \mathrm{HCl}(\mathrm{pH} 7 \cdot 6) / 1 \mathrm{M} \mathrm{NaCl}$ to which was added an equal volume of $1.3 \%(\mathrm{w} / \mathrm{v})$ low-meltingpoint agarose (BRL). The resuspended bacteria were then aliquoted to precooled $0.1 \mathrm{ml}$ plug moulds (Pharmacia) and allowed to solidify at $4{ }^{\circ} \mathrm{C}$ for $30 \mathrm{~min}$. Spheroblasting and deproteination were undertaken as described by Smith et al. (1988). Prior to restriction enzyme digestion, inserts were washed in $3 \times 10 \mathrm{ml}$ aliquots of $10 \mathrm{mM}$ Tris $/ \mathrm{HCl}(\mathrm{pH} \mathrm{7.5)/}$ $1 \mathrm{mM}$ EDTA (TE) at $37^{\circ} \mathrm{C}$ for a minimum of $2 \mathrm{~h}$ per wash.

Digestion with restriction enzymes was performed in a total volume of $0.3 \mathrm{ml}$, with 20-30 U of enzyme per insert. SmaI, SalI and BssHII (Boehringer Mannheim) digests were incubated overnight at $25^{\circ} \mathrm{C}, 37^{\circ} \mathrm{C}$ and $50^{\circ} \mathrm{C}$, respectively. NarI (BRL) restriction enzyme digests were incubated for $7 \mathrm{~h}$ at $37^{\circ} \mathrm{C}$ to avoid DNA degradation observed under more prolonged incubation conditions.

Electrophoresis. PFGE was undertaken using a contourclamped homogeneous-electric field (CHEF) apparatus with programmable, autonomously controlled digital/analogue convertors at each electrode (PACE system) (LKB 2015 Pulsaphor gel electrophoresis unit and pulse time controller; Pharmacia LKB Biotechnology). DNA samples were loaded onto $1 \%$ agarose (ICN Biomedicals) and run in $0.5 \times$ TBE buffer (Sambrook et al., 1989) at $14^{\circ} \mathrm{C}$. Optimal resolution of the SalI, NarI and BssHII restriction fragments used to construct the physical map of $C$. upsaliensis was achieved using pulse times linearly ramped from 5 to $45 \mathrm{~s}$ over the course of $21 \mathrm{~h}$ with a field strength of $10 \mathrm{~V} \mathrm{~cm}^{-1}$. Lambda concatemers (Promega) and the chromosomes of Saccharomyces cerevisiae, strain YPH149 (Kim et al., 1992), were used as size markers. For the purposes of hybridization fingerprint analysis, C. upsaliensis SmaI restriction digests were resolved in $1.2 \%$ agarose using pulse times linearly ramped from 2 to $5 \mathrm{~s}$ for $24 \mathrm{~h}$. Gels were stained for $30 \mathrm{~min}$ in ethidium bromide $\left(0.5 \mathrm{mg} \mathrm{ml}^{-1}\right)$, destained overnight and photographed under ultraviolet light.

Southern hybridization. Chromosomal DNA fragments from pulsed-field gels were transferred onto GeneScreen Plus nylon membrane (Dupont-NEN) using a Vacugene apparatus (Pharmacia). The gel was depurinated in $0.25 \mathrm{M} \mathrm{HCl}$, denatured in $0.5 \mathrm{M} \mathrm{NaOH} / 0.5 \mathrm{M} \mathrm{NaCl}$, neutralized in $1 \mathrm{M}$ Tris (pH 7.5)/1.5 M NaCl and transferred in $20 \times \mathrm{SSC}[3 \mathrm{M} \mathrm{NaCl} /$ $0 \cdot 3 \mathrm{M}$ sodium citrate ( $\mathrm{pH} 7)]$.

Library preparation. High molecular mass genomic DNA was isolated from $C$. upsaliensis ATCC 43954 according to the procedure of Thomas et al. (1966). Following extraction, purification and partial digestion with Sau3A1, the DNA was fractionated through a sucrose gradient and fragments in the size range 9-23 kb were isolated (Sambrook et al., 1989). This DNA was then ligated into phage lambda GEM-11 Bam HI arms (Promega) and recombinants were packaged with Packagene Extracts (Promega). After titration, the library was estimated to contain $2.5 \times 10^{4}$ recombinant clones. With an average insert size of $16 \mathrm{~kb}$, the library is, thus, approximately 200 times the genome size. Nine hundred and sixty individual phage plaques were harvested and stored in 96-well titre plates. Phage DNA was harvested from individual clones as described by Grossberger (1987). Aliquots of each recombinant phage clone from the lambda library were blotted (Hybridot Manifold, BRL) to nylon membrane (GeneScreen) for subsequent dot-blot hybridization. DNA fragments used to probe blots of the genomic digests and to screen the lambda library were labelled with $\left[\alpha-{ }^{32} \mathrm{P}\right] \mathrm{dATP}$ (ICN Biomedicals) by nick translation (Sambrook et al., 1989) and hybridized to the GeneScreen Plus membrane, using conditions recommended by the manufacturer.

\section{RESULTS}

\section{Electrophoretic analysis and genome size}

The restriction enzymes SalI $\left(5^{\prime} \mathrm{G} / \mathrm{TCGAC}\right)$, NarI (5' GG/CGCC) and BssHII (5' G/CGCGC) each cleaved the $C$. upsaliensis genome into an appropriate number of fragments for use in generating a physical map of the organism. SalI, NarI and BssHII produced 5, 8 and 10 restriction fragments, respectively (Table 1, Fig. 1). NruI (5' TCG/GCA), Xhol (5' C/TCGAG), BglI (5' GCCN4/NGGC), and two restriction enzymes found to be useful for mapping other Campylobacter species (Kim et al., 1992), SmaI (5' CCC/GGG), and SacII ( $5^{\prime} \mathrm{CCGC} / \mathrm{GG}$ ), cleaved the $C$. upsaliensis genome too frequently to be of use for macrophysical mapping. ApaI

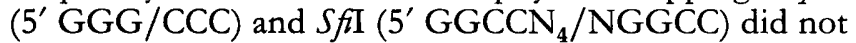
cleave the $C$. upsaliensis genome (data not shown).

The size of the C. upsaliensis ATCC 43954 genome was estimated at $2007 \mathrm{~kb}$ by adding together the sizes of the fragments from the SalI, NarI and BssHII digests and

\section{Table 1. PFGE fragment sizes for $C$. upsaliensis ATCC 43954}

Fragment sizes represent the mean of four independent PFGE runs. Electrophoresis conditions were altered during these runs. All 16 yeast chromsomes were fully resolved during one run to ensure accurate size estimation for higher molecular mass restriction fragments. The mean genome size for $C$. upsaliensis is $2007 \pm 67.5 \mathrm{~kb}$ ( \pm standard deviation).

\begin{tabular}{|lrrr|}
\hline \multirow{2}{*}{ Fragment } & \multicolumn{3}{c|}{ Fragment size (kb) } \\
\cline { 2 - 4 } & SalI & NarI & Bss HII \\
\hline A & 665 & 560 & 490 \\
B & 615 & 410 & 420 \\
C & 385 & 365 & 320 \\
D & 190 & 230 & 285 \\
E & 85 & 165 & 165 \\
F & & 125 & 130 \\
G & & 88 & 85 \\
H & & 63 & 65 \\
I & & & 60 \\
J & & & 55 \\
Total & 1940 & 2006 & 2075 \\
\hline
\end{tabular}


(a)

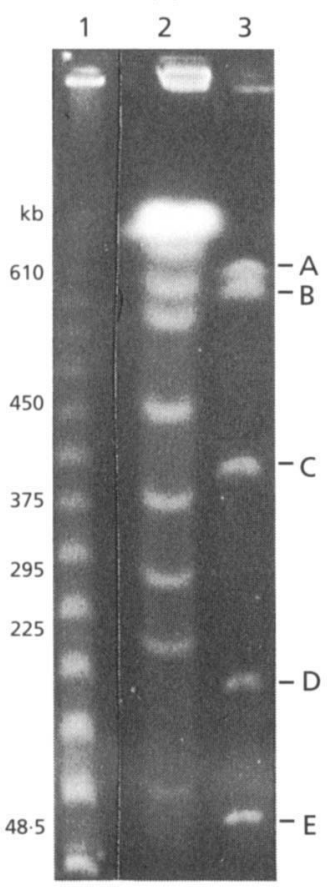

(b)

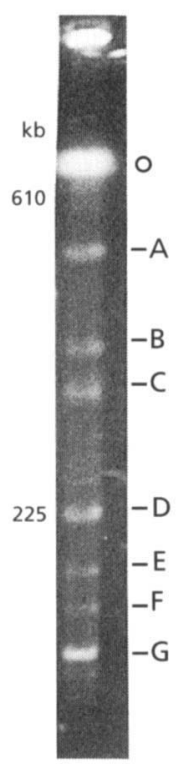

(c)

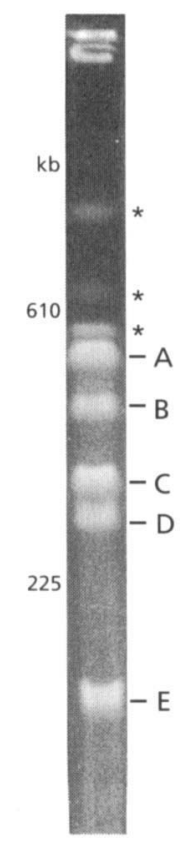

Fig. 1. PFGE gel of $C$. upsaliensis DNA. PFGE fragments are indicated alphabetically on the right and molecular sizes on the left side of each gel. Gels were run at $12-14^{\circ} \mathrm{C}$ in a field strength of $10 \mathrm{~V} \mathrm{~cm}^{-1}$. (a) Sall digest of C. upsaliensis DNA (lane 3). A $1 \%$ agarose gel was run for $21 \mathrm{~h}$ using a pulse time linearly ramped from 5 to $45 \mathrm{~s}$. Lambda concatemers (lane 1) and yeast chromosomes (lane 2) were used as size markers. (b) Narl digest of $C$. upsaliensis DNA. Electrophoresis conditions were as for (a). The unresolved, high molecular mass, strongly staining band in the Narl digest (O) represents uncut genomic DNA. Some variation in PFGE band intensity is seen. This probably represents differences in the efficiency of cleavage of Narl recognition sites in the genomic DNA. Narl $H$ is not visible in this digest. (c) BssHII digest of $C$. upsaliensis DNA. A $1.1 \%$ gel was run for $30 \mathrm{~h}$ using a pulse time linearly ramped from 5 to $50 \mathrm{~s}$. Three fainter bands representing partially digested DNA are indicated by asterisks. Some of the smaller BssHII fragments are not well visualized on this gel.

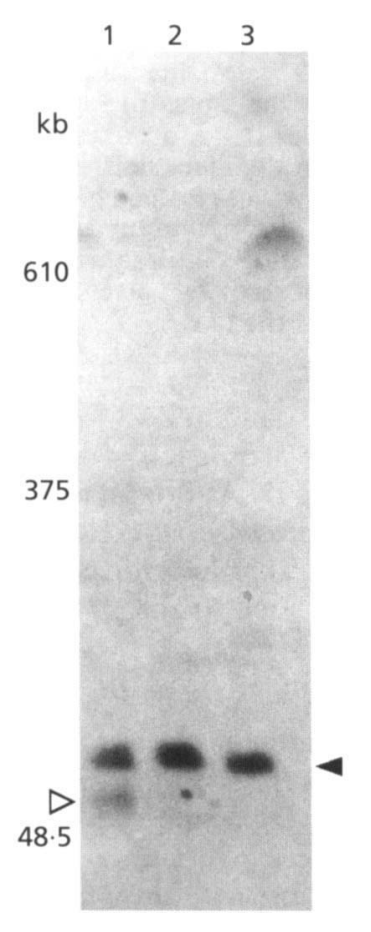

Fig. 2. Southern hybridization of a PFGE gel of $C$. upsaliensis ATCC 43954 probed with BssHII G fragment. The gel was run for $21 \mathrm{~h}$ using a pulse time linearly ramped from 5 to $45 \mathrm{~s}$ and $a$ field strength of $10 \mathrm{~V} \mathrm{~cm}^{-1}$. Molecular sizes are indicated to the left of the blot. Lanes 1-3 indicate BssHII, Narl and Sall digests, respectively. The black arrowhead indicates BssHII G, Narl G and Sall $E$ bands identified by the radiolabelled probe. The open arrowhead indicates anomalous hybridization to the Bss HII H fragment. taking the mean value from four independent PFGE runs utilizing different electrophoresis conditions (Table 1).

\section{Physical and genetic mapping of the genome}

Three complementary methods were employed to align restriction fragments from SalI, NarI and BssHII restriction digests into a physical map of the $C$. upsaliensis genome.

(i) Cross-Southern hybridization. Individual bands from each restriction digest were isolated and purified from agarose gels (GeneClean; Bio 101) and labelled with $[\alpha-$ $\left.{ }^{32} \mathrm{P}\right] \mathrm{dATP}$. These ${ }^{32} \mathrm{P}$-labelled pulsed-field fragments were then used to probe blots of genomic digests created by the other restriction enzymes (Fig. 2) (Kim et al., 1992; Ladefoged \& Christiansen, 1992; Neumann et al., 1993).

Cross-Southern hybridization using SalI fragments as probes allowed unambiguous localization of the majority of Bss HII and NarI restriction fragments and suggested a preliminary construct of the physical map. With SalI restriction fragments arranged as the outermost ring, regional arrangements of fragments from the three restriction digests were, for the most part, not difficult to infer. However, some ambiguous data accrued from the cross-hybridization experiments. The majority of anomalous cross-hybridizations were probably the consequence of random DNA degradation (Lee et al., 1989) or nonspecific endonucleases contaminating commercial restriction enzyme preparations (Allerdet-Servent et al., 1991). For instance, SaII C and NarI G hybridized to each other. However, other restriction fragments that aligned with 
Table 2. PFGE fragment cross-Southern hybridization patterns for C. upsaliensis ATCC 43954

For clarity, inconsistent cross-hybridization data have been omitted (discussed in the text).

\begin{tabular}{|c|c|c|c|}
\hline \multirow[t]{2}{*}{ Probe } & \multicolumn{3}{|c|}{ Fragment identified } \\
\hline & SalI & BssHII & NarI \\
\hline \multicolumn{4}{|l|}{ SalI } \\
\hline A & & $\mathrm{C}, \mathrm{D}, \mathrm{E}, \mathrm{G}$ & $A, G$ \\
\hline $\mathrm{B}$ & & $\mathrm{A}, \mathrm{B}$ & $\mathrm{B}, \mathrm{C}$ \\
\hline C & & $\mathrm{B}, \mathrm{C}$ & $\mathrm{C}, \mathrm{D}, \mathrm{E}, \mathrm{F}$ \\
\hline $\mathrm{D}$ & & $\mathrm{B}$ & $\mathrm{C}$ \\
\hline $\mathrm{E}$ & & $\mathrm{G}, \mathrm{H}$ & $\mathrm{G}, \mathrm{H}$ \\
\hline \multicolumn{4}{|c|}{ BssHII: } \\
\hline A & B & & $\mathrm{B}^{*}$ \\
\hline $\mathrm{B}$ & $\mathrm{B}, \mathrm{C}, \mathrm{D}$ & & $\mathrm{C}, \mathrm{D}$ \\
\hline $\mathrm{C}$ & $\mathrm{A}, \mathrm{C}$ & $\mathrm{D} \dagger$ & $\mathrm{A}, \mathrm{E}, \mathrm{F}$ \\
\hline $\mathrm{D}$ & A & $\mathrm{C}+$ & A \\
\hline $\mathrm{E}$ & $A, C$ & & A \\
\hline $\mathrm{G}$ & $\mathrm{E}$ & $\mathrm{H}$ & G \\
\hline \multicolumn{4}{|l|}{ NarI: } \\
\hline A & A & $\mathrm{C}, \mathrm{D}, \mathrm{E}$ & \\
\hline B & $\mathrm{B}$ & $\mathrm{A}$ & \\
\hline $\mathrm{D}$ & $\mathrm{C}, \mathrm{E}$ & $\mathrm{B}, \mathrm{C}$ & \\
\hline G & $\mathrm{A}, \mathrm{E}$ & $G, C$ & \\
\hline
\end{tabular}

* Unexpectedly, Bss HII A did not hybridize to the NarI C fragment (see text).

† BssHII C and BssHII D mapped strongly to each other, suggesting the presence of a large repetitive sequence in this region of the chromosome (see text).

NarI G (i.e. SalI E and BssHII G) did not cross-hybridize with SalI C. A number of other inconsistent hybridizations of this nature, mainly involving other BssHII and NarI fragments, were also noted. DNA degradation was a feature of restriction enzyme digestion with both NarI and Bss HII and probably accounts for the frequency of these inconsistent hybridizations in this study. In fact, as a consequence of DNA degradation among the smaller NarI and Bss HII fragments, only NarI $G$ and BssHII $G$ were useful as probes during crossSouthern experiments. The NarI G and BssHII G fragments were preferentially cleaved during digestion of some DNA preparations and could be isolated from agarose in quantities large enough to ensure a favourable signal-to-noise ratio during probing.

Because the unexpected hybridizations outlined above were only observed between selected fragments in each chromosomal location, they cannot be explained on the basis of hybridization to homologous multicopy genes occurring in different chromosomal locations (Neumann et al., 1993). However, the presence of homologous multicopy genes probably provides the explanation for some of the other ambiguous hybridization patterns. For instance, a large area of DNA homology provides a likely

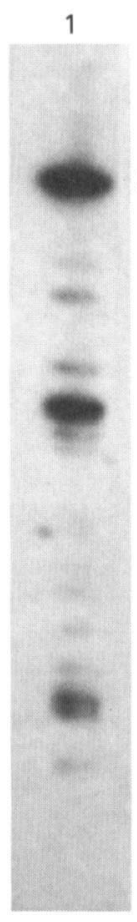

240

180

90 (a) $\mathrm{kb}$ 2
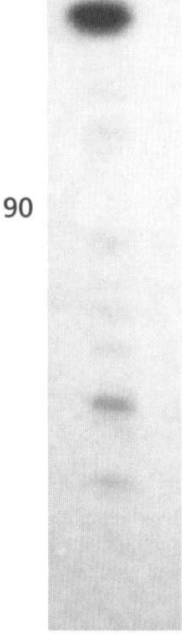

(b)

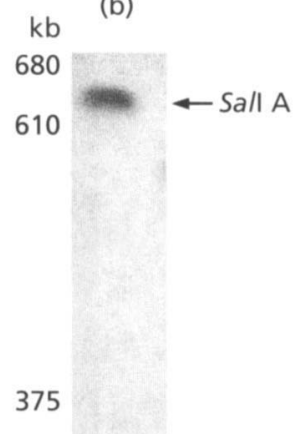

$48 \cdot 5$
Fig. 3. (a) Smal hybridization fingerprint for Sall C and Sall D fragments. Smal-digested C. upsaliensis DNA was resolved in $1.2 \%$ agarose using pulse times linearly ramped from 2 to $5 \mathrm{~s}$ for $24 \mathrm{~h}$. Southern blots 1 and 2 indicate Smal digests probed with Sall C and Sall D fragments, respectively. Molecular sizes are indicated between the blots. (b) Southern blot of Sall digest probed with Smal 'a-e' band, a putative linking fragment for Sall $A$ and $E$ previously identified by hybridization fingerprinting. The Sall digest was resolved in $1 \%$ agarose run for $21 \mathrm{~h}$ using a pulse time linearly ramped from 5 to $45 \mathrm{~s}$ and a field strength of $10 \mathrm{~V} \mathrm{~cm}^{-1}$. Sall fragments that hybridized with Smal 'a-e' are indicated by arrows. Molecular sizes are indicated to the left of the blot.

explanation for the strong cross-hybridization between BssHII C and BssHII D. Although neither the $16 \mathrm{~S}$ nor $23 \mathrm{~S}$ rRNA genes hybridized to Bss HII D, a number of other conserved gene markers hybridized with equal intensity to both of these loci (Table 3). This indicates the likelihood that this area of the genome contains an extensive duplication.

On the basis of fragment sizes, some overlap would be expected between BssHII C and NarI D and also between BssHII A and NarI C. Unexpectedly, cross-hybridizations did not confirm these overlaps. There are a number of possible explanations for this finding. Unfavourable signal-to-noise ratios may have obscured the result due either to small regions of overlap between two restriction fragments relative to their total size (Neumann et al., 1993) or to relatively inefficient DNA labelling in the regions of overlap because of local DNA configurations. Alternatively, some smaller, as yet unmapped, DNA fragments may ultimately 'fill in' these apparent gaps. In this respect it should be noted that BssHII F, BssHII I and $B s s \mathrm{HII} \mathrm{J}$ have not yet been placed onto this map. 
Table 3. Assignment of genetic markers to the physical map of C. upsaliensis ATCC 43954

\begin{tabular}{|c|c|c|c|c|c|}
\hline \multirow[t]{2}{*}{ Probe } & \multirow[t]{2}{*}{ Gene function } & \multicolumn{3}{|c|}{ Fragment identified } & \multirow[b]{2}{*}{ Source } \\
\hline & & SalI & NarI & BssHII & \\
\hline \multicolumn{6}{|c|}{ Homologous probes } \\
\hline $\operatorname{gly} A$ & Serine hydroxymethyltransferase & $\mathrm{D}$ & $\mathrm{C}$ & B & $\begin{array}{l}\text { S. T. Al Rashid \& V. L. } \\
\text { Chan (unpublished) }\end{array}$ \\
\hline$\lambda u b f r 3-1 *$ & Lambda library phage clone & $\mathrm{D}$ & $\mathrm{C}$ & $\mathrm{B}$ & \\
\hline$\lambda u b f l 1-1 *$ & Lambda library phage clone & $\mathrm{B}$ & B & A & This work \\
\hline$\lambda u b f z^{1-1 *}$ & Lambda library phage clone & A & A & $\mathrm{C}, \mathrm{D} \dagger$ & \\
\hline \multicolumn{6}{|c|}{$\begin{array}{l}\text { Heterologous probes } \\
\text { (C. jejuni) }\end{array}$} \\
\hline $\operatorname{fla} A$ & Flagellin A subunit & $\mathrm{A}, \mathrm{B} \ddagger$ & $\mathrm{A}, \mathrm{B} \ddagger$ & $\mathrm{E}, \mathrm{A} \ddagger$ & Khawaja et al. (1992) \\
\hline $\operatorname{fg} G$ & Flagellar basal body rod protein & A & A & $\mathrm{C}, \mathrm{D}+$ & Kim et al. (1993) \\
\hline flgF & Flagellar basal body rod protein & $\mathrm{A}$ & A & $\mathrm{C}, \mathrm{D}+\mathrm{Z}$ & H. Louie \& V. L. Chan \\
\hline fts $Z$ & Cell division protein & A & A & $\mathrm{C}, \mathrm{D}+\}$ & (unpublished) \\
\hline fur & Iron-uptake regulatory protein & $\mathrm{D}$ & $\mathrm{C}$ & B & $\begin{array}{l}\text { V. L. Chan and others } \\
\text { (unpublished) }\end{array}$ \\
\hline iles & Isoleucine-tRNA synthetase & $\mathrm{A}$ & A & $\mathrm{C}$ & Hong et al. (1995) \\
\hline lys & Lysyl-tRNA synthetase & $\mathrm{D}$ & $\mathrm{C}$ & B & Chan \& Bingham (1992) \\
\hline $\operatorname{tr} \times B$ & Thioredoxin reductase & $\mathrm{C}$ & $\mathrm{F}$ & $\mathrm{C}$ & $\begin{array}{l}\text { H. Louie \& V. L. Chan } \\
\text { (unpublished) }\end{array}$ \\
\hline $60 \mathrm{kDa}$ & Unknown & $\mathrm{C}$ & $\mathrm{D}$ & B & $\begin{array}{l}\text { Y. Hong and others } \\
\text { (unpublished) }\end{array}$ \\
\hline $16 \mathrm{~S}$ rRNA & Ribosomal RNA & $A, B, C$ & $A, B, C, D, G$ & $A, C, E\}$ & Kim et al (1993) \\
\hline $23 \mathrm{~S}$ rRNA & Ribosomal RNA & A, B, D & $\mathrm{A}, \mathrm{B}, \mathrm{C}$ & $A, B, C\}$ & Nim et at. (19ソว) \\
\hline
\end{tabular}

* $\lambda u b f r 3-1, \lambda u b f 1-1$ and $\lambda u b f\{1-1$ were identified by $C$. jejuni fur, fla $A$ and $f t s Z$ probes, respectively.

$\dagger$ Probes which hybridized to two separate BssHII fragments within the SalI A/NarI A fragments, suggesting the presence of a chromosomal duplication in this region.

$\ddagger$ In addition to the BssHII E/SalI A/NarI A locus, flaA probed less strongly to BssHII A/SalI B/NarI B, C fragments (see text for discussion).

Despite apparent anomalies during cross-hybridization, this mapping technique functioned well as the primary tool in generating the physical map. The positions of the majority of restriction fragments could be correctly inferred using this mapping method alone. These alignments were then confirmed by using the complementary strategies detailed below.

(ii) Hybridization fingerprint analysis. SmaI cleaved the $C$. upsaliensis genome into more than 25 fragments, a number too great to be of use for physical mapping. However, this restriction enzyme was useful for hybridization fingerprinting (Neumann et al., 1993). Radiolabelled SalI restriction fragments were used to probe $S m a$ I digests of C. upsaliensis DNA. By comparing hybridization signal patterns generated by the individual $S a l I$ restriction fragment probes it was possible to identify $S m a$ fragments which linked the $S a l$ fragments (Fig. 3a). This approach helped confirm the alignment of the SalI fragments in relation to each other.

(iii) Southern hybridization of genetic markers. Nine genetic markers previously cloned and sequenced in $C$. jejuni strain TGH9011 (ATCC 43431) (Chan \& Bingham, 1992; Khawaja et al., 1992; Kim et al., 1993; H. Louie \& V. L. Chan, unpublished data; Y. Hong and others, unpublished data) were used as probes to create a genetic map of the $C$. upsaliensis genome (Table 3). Fragments of the encoding regions of each of these genes were hybridized to digests of $C$. upsaliensis DNA, thereby defining these genetic loci on the $C$. upsaliensis chromosome. In addition, the $f l a A$ (Khawaja et al., 1992), fts $Z$ (H. Louie \& V. L. Chan, unpublished data) iron-uptake regulatory ( fur) (V. L. Chan and others, unpublished data) genes of $C$. jejuni were used to screen the lambda library for recombinant clones containing the homologous genes in C. upsaliensis. Single clones representing each of these probes, and the $C$. upsaliensis serine hydroxymethyltransferase $(g l y A)$ gene (S. T. Al Rashid \& V. L. Chan, unpublished data), were used as homologous probes and localized to the map (Fig. 4). Although $C$. upsaliensis library clone $\lambda u b f 1-1$ was identified by a $C$. jejuni fla $A$ probe, $\lambda u b f 1$-1 hybridized to a chromosomal locus identified only weakly by $f a A$ (i.e. SalI B/BssHII/NarI $\mathrm{B}, \mathrm{C})$. This probably indicates the presence of a gene 


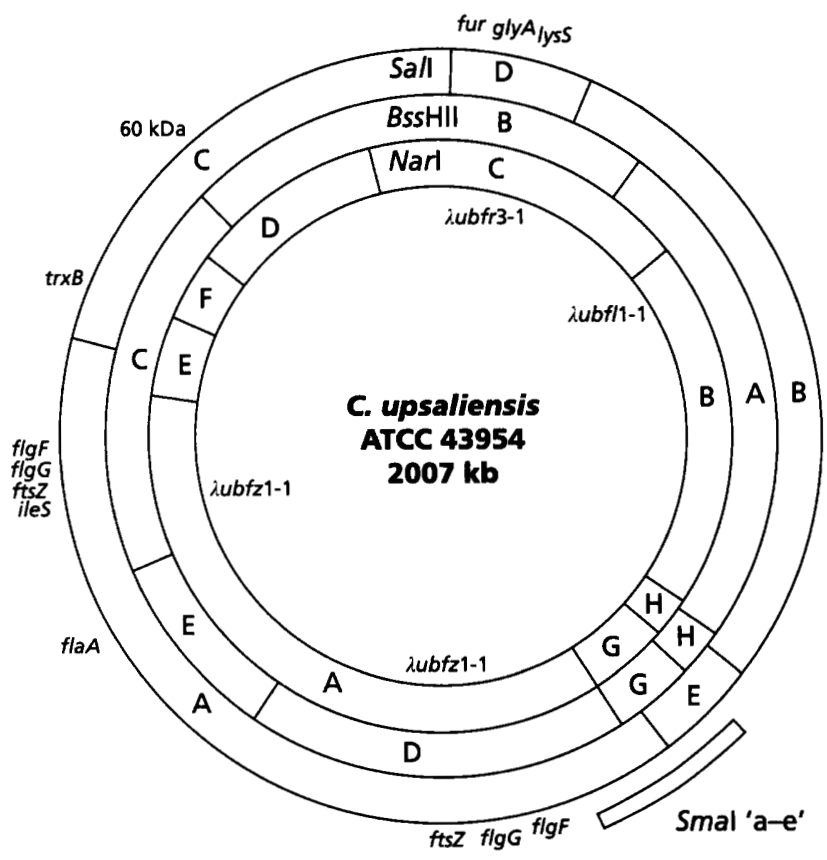

Fig. 4. The physical map of C. upsaliensis ATCC 43954 generated with Sall, BssHII and Narl. Restriction fragments are designated alphabetically as indicated in the text. The location of genetic probes from C. jejuni, C. upsaliensis lambda library clones and the Smal ' $a-e$ ' linking fragment are indicated.

homologous to $f a A$ in this region. As expected, $16 \mathrm{~S}$ and 23S ribosomal RNA genes of $C$. jejuni (Kim et al., 1993) localized to multiple fragments on the physical map (Table 3). Therefore, the individual rRNA genes could not be unequivocally localized on the physical map of C. upsaliensis.

\section{Construction of the map}

Cross-Southern hybridization allowed confident alignment of the majority of restriction fragments. The left end of $S a l I \mathrm{D}$ was aligned at $0^{\circ}$ on the physical map. With $B s s \mathrm{HII} \mathrm{B}$ acting as linking fragment, $S a l \mathrm{I}$ B was positioned adjacent to SalI D in a clockwise direction. Bss HII A, NarI B and NarI C were aligned with these SalI fragments on the basis of cross-hybridization pattern and fragment size.

Working clockwise, SalI E defined a locus containing the $\mathrm{G}$ and $\mathrm{H}$ fragments of BssHII and NarI digests. This alignment was based on strong reciprocal hybridizations between these fragments. The possible alternative of placement of the SalI E locus between SalI A and SalI C was resolved by assuming that the unambiguous crosshybridization pattern generated by Bss HII G (Fig. 2) was correct. In this case, the alternative arrangement of this locus between $S a l I A$ and $S a l I C$ was untenable on the basis that BssHII G could not replace BssHII C as a linking fragment for SalI A and Sall C. This assumption was confirmed by hybridization with the SmaI 'a-e' fragment. $S m a I$ ' a-e' hybridized to SalI E and Sall A (Fig. 3b), indicating the contiguity of these two fragments. Furthermore, SmaI 'a-e' hybridized to Bss HII G, Bss HII H and NarI G but not NarI H (data not shown). This confirmed the alignment of BssHII G and NarI G fragments in relation to $S a l l \mathrm{E}$ and documented the orientation of the $\mathrm{G}$ and $\mathrm{H}$ fragments of these digests in relation to adjacent restriction fragments (i.e. the $\mathrm{H}$ fragments both lie anticlockwise of the $G$ fragments).

Sall A overlapped the G fragments of both Bss HII and $N a r I$ digests and also hybridized to Bss HII C, Bss HII D, BssHII E and NarI A. The position of NarI A was apparent on the basis of its size and its failure to hybridize with other $S a l \mathrm{I}$ fragments. Bss HII C was known to be located at the clockwise extreme of SalI A because it served as a linking fragment with the adjacent SalI C fragment. BssHII D is located at the other extreme of $S a l I$ $A$ as it was identified by the $S m a I$ ' a-e' probe (data not shown). By inference, BssHII E must align between BssHII C and BssHII D in the centre of the SalI A and NarI A fragments. The position of the BssHII E fragment was then confirmed in this location by its hybridization with $f a A$ from $C$. jejuni.

Completing the circle of the physical map, SalI C hybridized to BssHII C and BssHII B. The arrangement of NarI D clockwise to NarI E and NarI F was then inferred on the basis of hybridization patterns with BssHII B and BssHII C fragments.

Hybridization fingerprinting confirmed the contiguity of the Sall fragments inferred from cross-hybridization experiments (Fig. 3a). Localization of conserved genetic markers was then employed to support the alignment of restriction fragments on the physical map. Hybridization fingerprinting and hybridization with conserved genetic markers effectively eliminated those ambiguities encountered during cross-hybridization experiments.

\section{DISCUSSION}

We have constructed the first physical and genetic map of the genome of $C$. upsaliensis. This study also provides the first estimate of the genome size of this organism. To date, PFGE has been used to determine the genome sizes of three other Campylobacter species (Chang \& Taylor, 1990; Nuijten et al., 1990; Yan \& Taylor, 1991; Kim et al., 1992; Salama \& Taylor, 1993), which vary from $1125 \mathrm{~kb}$ for $C$. fetus subsp. fetus (Salama \& Taylor, 1993) to $1812 \mathrm{~kb}$ for C. jejuni (Kim et al., 1992). At $2007 \mathrm{~kb}$, C. upsaliensis is the largest campylobacter genome sized to date.

During PFGE of $C$. upsaliensis DNA, the presence of a number of partially digested Bss HII and NarI fragments was a consistent feature of restriction digestion with these enzymes (Fig. 1b, c). More complete digestion of $C$. upsaliensis DNA with Bss HII resulted in partial cleavage of the BssHII A fragment into 390 and $100 \mathrm{~kb}$ fragments. The presence of the $100 \mathrm{~kb}$ fragment was also sometimes noted on gels following standard BssHII restriction digestion. In addition, more complete digestion of $C$. upsaliensis DNA with NarI utilizing longer incubation times resulted in significant amounts of DNA degra- 


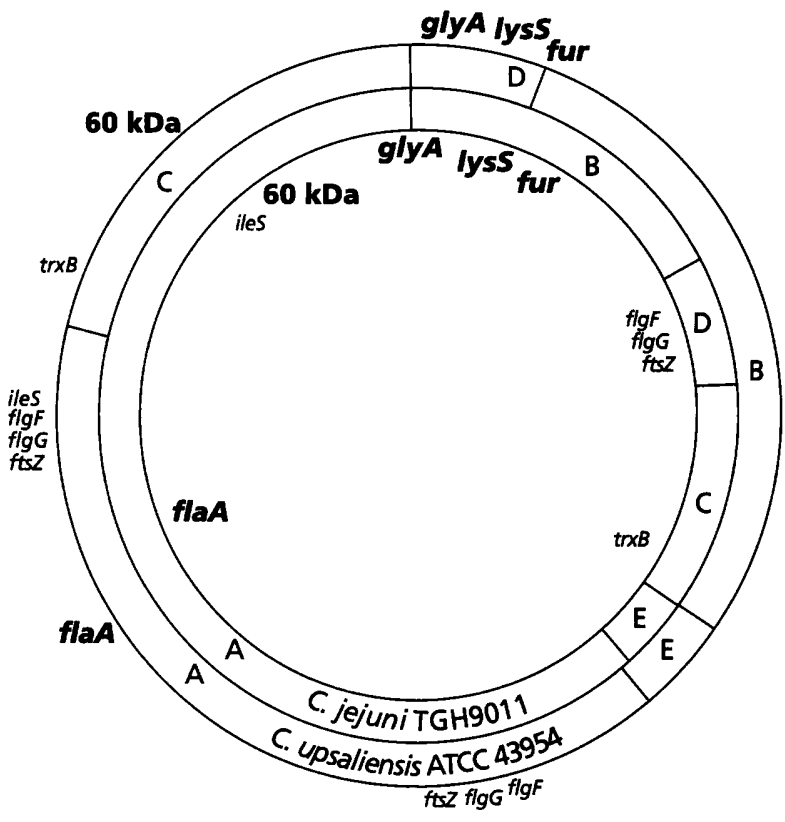

Fig. 5. Comparison between the genomic maps of $C$. upsaliensis and $C$. jejuni. The outer circle represents the Sall restriction map of C. upsaliensis ATCC 43954. The inner circle represents the Sall restriction map of $C$. jejuni TGH9011 (Kim et al., 1992). The two maps were aligned on the basis of fla, glyA, lyss, fur and $60 \mathrm{kDa}$ gene loci, indicated in bold type. Genetic loci not sharing a common alignment on the two maps are indicated in small print.

dation. NarI-undigested DNA is seen on the gel as an unresolved, strongly staining, high molecular mass band (Fig. 1b). The C. upsaliensis type strain used in this study (ATCC 43954/NCTC 11541 was also resistant to digestion using a restriction enzyme (HaeIII) that was employed in a previous study (Owen \& Hernandez, 1990).

The use of a number of complementary techniques during physical mapping of the $C$. upsaliensis genome facilitated the construction of a more detailed and accurate map. Cross-Southern hybridization patterns allowed preliminary alignment of the majority of restriction fragments (Table 2). Hybridization fingerprinting (Fig. 3a) and hybridization with genetic markers clarified ambiguities arising from unexpected cross-hybridizations between fragments positioned at different chromosomal locations.

Ambiguous hybridization patterns during crosshybridization may be explained either by the presence of repetitive genes or operons in the $C$. upsaliensis genome (Neumann et al., 1993) or by non-specific hybridization due to DNA degradation (Allerdet-Servent $e t$ al., 1991). DNA degradation presented a confounding variable during digestion using NarI and Bss HII and is, therefore, the likely cause of the majority of unexpected and inconsistent hybridization signals in this study. However, the presence of repetitive sequences in the genome of $C$. upsaliensis provides the likely explanation for some ambiguities encountered during the construction of the physical map. In particular, cross-hybridization and localization of gene markers strongly suggests that the $C$. upsaliensis genome contains an extensive duplication generated through unequal cross-over between multicopy genes. This extensive duplication in the area of BssHII C and BssHII D could account for the observed large genome of $C$. upsaliensis relative to other campylobacters. This region of cross-homology does not appear to be due to the presence of a conserved rRNA operon as neither $16 S$ rRNA nor 23S rRNA genes localize to the BssHII D fragment (data not shown). The presence of extensive areas of cross-homology has not been noted during mapping studies of other Campylobacter species (Chang \& Taylor, 1990; Nuijten et al., 1990; Kim et al., 1992).

A comparison of the genomic map of $C$. upsaliensis with that of $C$. jejuni TGH9011 is shown in Fig. 5. This comparison was based on five genetic loci (fla, fur, lys $S$, gly $A$ and the $60 \mathrm{kDa}$ gene), the relative positions of which were conserved on both maps. Future studies aimed at localization to the $C$. upsaliensis genomic map of other conserved genetic loci, including the origin of replication and rRNA genes, will be used to verify this alignment and to allow comparison with the genomic maps of other Campylobacter species (Nuijten et al., 1990; Yan \& Taylor, 1991; Salama \& Taylor, 1993).

A primary objective of this mapping project was to localize potential virulence genes for $C$. upsaliensis to the genome. To this end, the genetic loci for the flagellin A subunit $(f a A)$ and iron-uptake regulatory ( $f u r)$, genes have been established on the $C$. upsaliensis physical map. A number of genetic loci representing genes serving other important physiological functions for this organism have also been identified. It is expected that with the identification and localization of other genes for $C$. upsaliensis, this genetic map will grow in complexity and function as a benchmark for further molecular biological studies of this emerging human enteropathogen.

\section{ACKNOWLEDGEMENTS}

We gratefully acknowledge $\mathrm{H}$. Bingham for her excellent technical assistance throughout this study.

B. Bourke is the recipient of a Research Fellowship Award from the Medical Research Council of Canada. P. Sherman is the recipient of a career scientist award from the Ontario Ministry of Health. This work was supported by grants from the Medical Research Council of Canada.

\section{REFERENCES}

Allardet-Servent, A, Carles-Nurit, M. J., Bourg, G., Michaux, S. \& Ramuz, M. (1991). Physical map of the Brucella melitensis $16 \mathrm{M}$ chromosome. J Bacteriol 173, 2219-2224.

Alleman, A. R., Kamper, S. M., Viseshakul, N. \& Barbet, A. F. (1993). Analysis of the Anaplasma marginale genome by pulsed-field electrophoresis. J Gen Microbiol 139, 2439-2444.

Chan, V. L. \& Bingham, H. L. (1992). Lysyl-tRNA synthetase gene of Campylobacter jejuni. J Bacteriol 174, 695-701.

Chang, N. \& Taylor, D. E. (1990). Use of pulsed-field agarose gel electrophoresis to size genomes of Campylobacter species and to 
construct a SalI map of Campylobacter jejuni UA580. J Bacteriol 172, 5211-5217.

Chusid, M. J., Wortmann, D. W. \& Dunne, W. M. (1990). 'Campylobacter upsaliensis' sepsis in a boy with acquired hypogammaglobulinemia. Diagn Microbiol Infect Dis 13, 367-369.

Goossens, H., Vlaes, L., DeBoeck, M., Pot, B., Kersters, K., Levy, J., De Mol, P., Butzler, J. P. \& VanDamme, P. (1990). Is 'Campylobacter upsaliensis' an unrecognised cause of human disease? Lancet $\mathbf{3 3 5}$, 584-586.

Grossberger, D. (1987). Minipreps of DNA from bacteriophage lambda. Nucleic Acids Res 15, 6737.

Honeycutt, R. J., McClelland, M. \& Sobral, B. W. S. (1993). Physical map of the genome of Rbizobium meliloti 1021. I Bacteriol 175, 6945-6952.

Hong, Y., Wong, T., Bourke, B. \& Chan, V. L. (1995). An isoleucyltRNA synthetase gene from Campylobacter jejuni. Microbiology 141, 2561-2567.

Khawaja, R., Neote, K., Bingham, H. L., Penner, J. L. \& Chan, V. L. (1992). Cloning and sequence analysis of the flagellin gene of Campylobacter jejuni TGH9011. Curr Microbiol 24, 213-221.

Kim, N. W., Bingham, H., Khawaja, R., Louie, H., Hani, E., Neote, K. \& Chan, V.L. (1992). Physical map of Campylobacter jejuni TGH9011 and localization of 10 genetic markers by use of pulsedfield gel electrophoresis. J Bacteriol 174, 3494-3498.

Kim, N. W., Lombardi, R., Bingham, H., Hani, E., Louie, H., Ng, D. \& Chan, V. L. (1993). Fine mapping of the three rRNA operons on the updated genomic map of Campylobacter jejuni TGH9011 (ATCC 43431). J Bacteriol 175, 7468-7470.

Ladefoged, S. A. \& Christiansen, G. (1992). Physical and genetic mapping of the genomes of five Mycoplasma hominis strains by pulsed-field gel electrophoresis. J Bacteriol 174, 2199-2207.

Lastovica, A. J., Le Roux, E. \& Penner, J. L. (1989). ' Campylobacter upsaliensis' isolated from blood cultures of pediatric patients. J Clin Microbiol 27, 657-659.

Lee, J. J. \& Smith, H. O. (1988). Sizing of the Haemophilus influenzae Rd genome by pulsed-field agarose gel electrophoresis. $J$ Bacteriol 170, 4402-4405.

Lee, J. J., Smith, H. O. \& Redfield, R. J. (1989). Organization of the Haemophilus Rd genome. J Bacteriol 171, 3016-3024.

Maslow, J. N., Slutsky, A. M. \& Arbeit, R. D. (1993). Application of pulsed-field gel electrophoresis to molecular epidemiology. In Diagnostic Molecular Microbiology: Principles and Applications, pp. 563-572. Edited by D. H. Persing, T. F. Smith, F. C. Tenover \& T. J. White. Washington, DC: American Society for Microbiology.

Megraud, F. \& Bonnet, F. (1986). Unusual camplyobacters in human feces. J Infect 12, 275-276.

Murray, B. E., Singh, K. V., Ross, R. P., Heath, J. D., Dunny, G. M. \& Weinstock, G. M. (1993). Generation of restriction map of Enterococcus faecalis OG1 and investigation of growth requirements and regions encoding biosynthetic function. $J$ Bacteriol 175, 5216-5223.

Neumann, B., Pospiech, A. \& Schairer, H. U. (1993). A physical and genetic map of the Stigmatella aurantiaca DW4/3.1 chromosome. Mol Microbiol 10, 1087-1099.

Nuijten, P. J. M., Bartels, C., Bleumink-Pluym, N. M. C., Gaastra,
W. \& van der Zeijst, B. A. M. (1990). Size and physical map of the Campylobacter jejuni chromosome. Nucleic Acids Res 18, 6211-6214.

Owen, R. J. \& Hernandez, J. (1990). Genotypic variation in Campylobacter upsaliensis from blood and faeces of patients in different countries. FEMS Microbiol Lett 72, 5-10.

Patton, C. M., Shaffer, N., Edmonds, P., Barrett, T. J., Lambert, M. A., Baker, C., Perlman, D. M. \& Brenner, D. J. (1989). Human disease associated with 'Campylobacter upsaliensis' (catalase-negative or weakly positive Campylobacter species) in the United States. J Clin Microbiol 27, 66-73.

Pyle, L. E., Corcoran, L. N., Cocks, B. G., Bergemann, A. D., Whitley, J. C. \& Finch, L. R. (1988). Pulsed-field electrophoresis indicates larger-than-expected sizes for mycoplasma genomes. Nucleic Acids Res 16, 6015-6025.

Romling, U., Grothues, D., Bautsch, W. \& Tummler, B. (1989). A physical genome map of Pseudomonas aeruginosa PAO. EMBO J 8 , 4081-4089.

Salama, S. M. \& Taylor, D. E. (1993). Construction of a genomic map of the chromosome of Campylobacter fetus subsp. fetus ATCC 27374. Acta Gastro-enterol Belg 56, 18.

Sambrook, J., Fritsch, E. F. \& Maniatis, T. (1989). Molecular Cloning: a Laboratory Manual, 2nd edn. Cold Spring Harbor, NY: Cold Spring Harbor Laboratory.

Sandstedt, K. \& Ursing, J. (1991). Description of the Campylobacter upsaliensis sp. nov. previously known as the CNW group. Syst Appl Microbiol 14, 39-45.

Sandstedt, K., Ursing, J. \& Walder, M. (1983). Thermotolerant Campylobacter with no or weak catalase activity isolated from dogs. Curr Microbiol 8, 209-213.

Smith, C. L., Econome, J. G., Schutt, A., KIco, S. \& Cantor, C. R. (1987). A physical map of the Escherichia coli K12 genome. Science 236, 1448-1453.

Smith, C. L., KIco, S. R. \& Cantor, C. R. (1988). Pulsed-field gel electrophoresis and the technology of large DNA molecules. In Genome Analysis: a Practical Approach, pp. 41-69. Edited by K. E. Davis. Oxford: IRL Press.

Steele, T. W., Sangster, N. \& Lanser, J. A. (1985). DNA relatedness and biochemical features of Campylobacter spp. isolated in Central and South Australia. J Clin Microbiol 22, 71-74.

Taylor, D. E., Hiratsuka, K. \& Mueller, L. (1989). Isolation and characterization of catalase-negative and catalase-weak strains of Campylobacter species, including 'Campylobacter upsaliensis', from humans with gastroenteritis. J Clin Microbiol 27, 2042-2045.

Thomas, C. A., Berns, K. I. \& Kelly T. J. (1966). Isolation of high molecular weight DNA from bacteria and cell nuclei. In Procedures in Nucleic Acid Research, pp. 535-540. Edited by G. L. Cantoni \& D. R. Druve. New York: Harper \& Row.

Walmsley, S. L. \& Karmali, M. A. (1989). Direct isolation of atypical thermophilic Campylobacter species from human feces on selective agar medium. J Clin Microbiol 27, 668-670.

Yan, W. \& Taylor, D. E. (1991). Sizing and mapping of the genome of Campylobacter coli strain UA417R using pulsed-field gel electrophoresis. Gene 101, 117-120.

Received 14 February 1995; revised 14 June 1995; accepted 23 June 1995. 